\title{
Are Secondary School Students Motivated to Learn Islamic Education?
}

\author{
Adam Adesina Muhammed-Lawal \\ PhD Student, Department of Curriculum and Instruction, \\ Kulliyyah of Education, International Islamic University Malaysia (IIUM) \\ Adnan Abd Rashid \\ Department of Curriculum and Instruction, Kulliyyah of Education, \\ International Islamic University Malaysia (IIUM) \\ Kamal J. I. Badrasawi \\ Department of Curriculum and Instruction, Kulliyyah of Education, \\ International Islamic University Malaysia (IIUM)
}

\begin{abstract}
The main aim for Islamic Education is to produce a 'good man' in all his personality aspects. This study aims to determine the level of secondary school students' motivation in learning Islamic Education subject, and to examine the factors influencing their motivation using the cross-sectional survey design. The study sample consisted of (170) students selected from an Islamic school in Malaysia using a nonrandom, quota sampling procedure to answer a 32-item questionnaire. The items measured four constructs: Students' Motivation (SM), Parental Influence (PI), Teaching Pedagogy (TP) and Teachers' Morality (TM) using a 5-point Likert scale. Descriptive statistics (Frequencies, Percentages, Means and Standard Deviations) and Pearson product-moment correlation coefficients were used to analyze the collected data. The results show that students' motivation in learning Islamic Education subject is quite high. The Islamic Education subject is important for students as it helps them appreciate and improve their life. Moreover, there were significantly positive relationships between the three factors (i.e. Parental Influence (PI), Teachers' Morality (TM), Teaching Pedagogy (TP) ) and Students' Motivation (SM). It is recommended that teachers of Islamic Education should use more interactive teaching methods to further motivate students to learn Islamic Education and be able to apply the contents in their life. There is a need for more quantitative research to be conducted on larger samples and using other statistical techniques. Qualitative research is also needed to get more in-depth information on students' motivation in learning Islamic Education.
\end{abstract}

Key words: Students' Motivation (SM), Parental-influence (PI), Teaching Pedagogy (TP) and Teachers' Morality (TM), Islamic Education.

\section{INTRODUCTION}

Islam as a universal religion appreciates and recommends knowledge acquisition for human development and recognition of Almighty Allah (s.w.t) as the Creator of cosmos. This is why the very first revelation to Prophet Muhammad (s.a.w) was specifically on the seeking of knowledge. Since its inception, Islam has given priority to education over all other things. This could be evidenced on the fact that the messenger of Allah (s.a.w) is seen as the teacher sent to the whole world to educate them the essence of life. This is also manifested in his actions, as he is a great teacher that really laid much value on education (Azeez \& Adeshina, 2013). Adnan Abd Rashid (2014) shared the same view that education in Islam is mainly a virtue in accordance with the Din al-Islam (religion of Islam). 
To attain high level of Iman (faith), the Holy Qur'an and Sunnah have given motivation to Muslims such as promise of Jannah (Paradise). Hence, the concept of motivation is very essential in Islam. Motivation has many different definitions, but it is important to focus on those that are related to the students' learning. Understanding the concept of motivation will help teachers decide what actions to take to encourage their students.

Alizi \& Mohammad (2005) stated that motivation in Islam can be seen in two types namely, the intrinsic and extrinsic motivation. Intrinsic motivation comes from one's own desire to achieve or overcome challenges. So, they do not need any incentive to encourage them to do any work. The satisfaction coming from the work itself is a reward for them. Extrinsic motivation, on the other hand, refers to motivation to perform a behavior in order to get rewards and avoid punishment. Abbas, Lei-Mei and Narjes (2012) found that in an endeavor to explicate motivation either intrinsic or extrinsic, it is necessary and vital to highlight some of the important related terms in order to have a wide-ranging understanding of the function and application of motivation in a learning environment. Among those terms essential for this task are stimulus, response and reward. For the first one, intrinsic motivation can be described as the satisfaction derives by one to engage in an activity because that activity is enjoyable and satisfying to do. Abbas et al. (2012) identified intrinsic motivation could be seen as a pleasure derived by one to partake or do a particular behavior. This means that it is an internal motive that works one up to be involved in such activity. For instance, if one recites the Holy Qur'an because of the concern and belief that it is divinely revealed, this is an example of intrinsic motivation. The objectives and contents of the curriculum in relation to the above mentioned goal could be considered as stimulus, while positive and negative students' interest towards the objectives and contents could be regarded as students' responses towards the subject matter. Extrinsic motivation is to involve oneself in certain activity because of material or concrete or physical reward or external influence. For example, memorize part area (i.e. chapter/surah) in the Holy Book (Qur'an) because it is part of course outline to pass a particular course or examination, this is extrinsic motivation. Learners depending on extrinsic motivation are those whose actions are carried out to achieve some instrumental end, such as, earning a reward or avoiding a punishment. In fact, there are several factors affect learners' motivation including parents, teaching pedagogy and teachers' morality.

\section{Parents}

According to Al-ghazzali as cited in Alvi (1988), "parents are the first teachers for their children. The education of their children is an important responsibility of the parents. If a child is given a good training of character, behavior and manner, he/she will surely follow the truth when grown up and with pleasure in this World and Hereafter, which will be shared by his parents". However, he emphasized that "lack of proper education ruins the child, and his sins too will be shared by their parents".

The perceptions and attitudes of parents on discipline go a long way in determining the learning of their children. Parents should be aware that the value of having morally upright sons and daughters cannot be underestimated. Aijaz as cited in Zaiton (2012) stated that parents' role is very important in the upbringing of their children in accordance with the teaching of Islam. He also mentioned seven responsibilities of parents for training and enlightening their children, which are: religious training or inculcation of faith, ethical training, academic training, physical training, development of personality training, sexual training and social training. Hence, Azeez \& Adesina (2013) opined that parents should provide their children with adequate text books and materials needed to complement teachers' effort. They should nurture their children well in moral and religious upbringing. They should encourage and convince their children to attend Islamic studies classes, right from childhood. More so, 
they should not discourage children from studying whatever they want to study, "in as much it does not go against Allah's Law"; rather they should encourage and motivate them, not enforce them to learn Islamic studies through which they will benefit in both Worlds.

\section{Pedagogy in Teaching Islamic Education Subject}

Adedoyin (2011) found that one of the characteristics of good teachers is that they keep a considerable amount of specialized knowledge which is stated to as pedagogical content knowledge (PCK). He also mentioned that, pedagogical content knowledge is the knowledge of how to convert the formal subject matter into meaningful outcomes for learners, and it similarly contains considerate of a specific topic and in what way instructors deliver the topic or concepts to make sense to the learners. That is, educators are constantly likely to display a basic set pedagogical knowledge and talents for the learners, which comprise a good knowledge of their teaching approaches, skills and understanding of learners' improvement.

Pedagogical Content Knowledge is where teachers need to psychologize a lesson's content clearly to students (Smith, 2005), which covers the knowledge of the subject's content, pedagogical knowledge of the subject, knowledge of the students' characteristics, the teacher's beliefs on the features of the subject and approaches to teaching, to produce effective education teaching. Abdul Rahman (1982) states that the status of the methods of teaching in education comes from the fact that the content of any curriculum cannot be learned competently and successfully except it is accessible in a particular way. Insufficiency of methods of teaching may handicap learning and cause undue wastage of struggle and time. In contrast, the characteristics of teaching pedagogical content knowledge involves at least three main components: 'knowledge of content', 'knowledge of teaching strategies' and 'knowledge of understanding students' combined with the values highlighted in Islamic Education (Mohd \& Ahmad 2012).

\section{Teachers' Morality}

Good manner is one of the Islamic educational goals; a loss of manner (adab) can cause error in knowledge and later on, it could lead to the rise of unqualified leaders in community (Al-attas 1979). Therefore, the training of manner ( $a d a b$ ) has been considered as a significant duty for teachers as well as educators. Henceforth, an understanding of how mentors or teachers are motivated pupils towards a positive work behavior of students within school compound is important (Mohd Shahril \& Sidek, 2013). Al-ghazali as cited in Rafiei (2002) defines morality "as a stable state of the soul by which it is possible for individual person to do good works easily and immediately. He points out that one-quarter of the Holy Book (Qur'an) is related to morality; 783 verses in the Qur'an concern pure morality and 748 verses are about applied morality. On this basis he claims that nothing else in teaching Islamic Education as significant as morality.

Chanika as cited in Samsoo, Mohd, Nordin, Sharifah and Sofiyah (2001), asserted that teacher is honored as the living example of Islamic culture and guide (murshid) to the thirsty young minds. Additionally, Yadullah (1999) described teachers as a murrabi or a person who combines a life of learning with a life of virtue, benefit and hence a perfect and an ideal person to learn from. According to him, the best model of a murrabi is the prophet Muhammad (s.a.w) as he does what he says, what he teaches and how to teach. Chanika in Samsoo et al. (2011) stated added that Islamic teachers have two roles: mu'allim and murrabi. First, mu'allim (teacher) is a teacher and mentor of the mind and a giver/whisperer of knowledge to the learner. Second, a Murrabi is defined as a trainer of the souls and characters, an advisor, and/or a role model to be follow. An individual, teacher or educator who holds personally responsible to mould good characters is a murabi. Like a teacher (mu'allim), there is also an 
understanding that the murabbi is answerable to Allah (s.w.t) for their appointments and how they use the command to affect, influence, encourage or discourage those in their care. Therefore, Islamic Education teachers should be dedicated, prompt and responsible for the accomplishment of the assigned work. They should be good role models for students and other people by means of strictly steadfast by Islamic teachings; and they should provide help to their students, be generous to them and construct good relationship with them. All these will motivate students in learning Islamic Education subject (Islamic studies). Other key roles that the concept of murabbī encompasses are found in (Badrasawi et al., 2017; Mohamad Johdi Salleh \& Abdul Karnaen, 2017).

Hamid (2007) suggested that teacher's task is thus not limited to the imparting of knowledge, but comprises concern for the rounded development of the students; including the personality, character, decision-making capacity and good behavior. The teacher is like a father to student and merits the same relationship of trust and respect. Indeed, the relationship between teacher and students is mutually beneficial; the students benefits from guidance and support as he grows towards moral maturity, and the teacher benefits from the opportunity to perform his moral obligation to pass on his wisdom and understanding. According to Adnan Abd Rashid (2014) explicated that Islamic education seeks "to promote and establish good in the life of an individual Muslim." Meaning that, Islamic Education seeks to inculcate "good moral qualities in man or woman and elevates his/her akhlaq to a higher and noble level."

Hence, this study aims to determine the level of secondary school students' motivation in learning Islamic education subject, and to investigate the factors influencing their motivation.

\section{RESEARCH METHOD}

This study used the quantitative cross-sectional survey method. Questionnaires were administered to a sample of (170) secondary students selected from an Islamic School in Malaysia using the non-random, quota sampling procedure. The questionnaire consists of four constructs; Students' Motivation (SM) (14 items), Parenting Influence (PI) (7 items), Teaching Pedagogy (TP) (6 items) and Teacher Morality (TM) (5 items). The 5-point Likert scale was used, ranging from 1= Strongly Disagree, 2= Disagree, $3=$ Neutral, 4= Agree and 5= Strongly Agree. The questionnaire was constructed based on previous literature review (e.g. Marwan, 2000; Mohd \& Ahmad, 2012; Oseni, 2012; Zaiton, 2012).

The survey content validity was determined by seeking the opinions of three experts from a Faculty of Education in a public university in Malaysia, while the reliability was determined through Cronbach's Alpha in SPSS software, version 22. The Cronbach Alpha values ranged from 0.76 to .87 , with an overall value of 0.80

\section{RESULTS}

Table 1 below shows the overall Means and Standard deviations of motivation and the three other factors i.e. Parental Influence (PI), Teachers' Morality (TM) and Teaching Pedagogy (TP). Overall students showed quite high motivation to learn Islamic education, (Mean $=3.58$ ). Furthermore, the Means of the three factors (PI, TM and TP) influencing students motivation in learning Islamic education were quite high $(3.55,3.60$ and 3.27) respectively. Such findings show that these factors might affect the students' motivation in learning Islamic Education, supported by the significant, positive Pearson correlation coefficient values for the three factors (PI, TM and PT) with students' motivation, $(.594,0.378,0.220, p<0.01)$ respectively (Table 2). The correlation size ranged from large to small (Cohen cited in Pallant, 2011, p.134). Meaning that high levels of parents' involvement, teachers' morality and teaching interactive pedagogy associated with high levels of students' motivation in learning Islamic Education. It 
is important to highlight that this correlation does not imply a causal link between the three variables and motivation (Pallant, 2011).

Table 1: Means and Standard Deviations of Motivation and Factors of Parents, Teachers Morality and Teaching Pedagogy

\begin{tabular}{lll}
\hline Factors & Means & Std \\
\hline Students' Motivation (SM) & 3.58 & .56 \\
& & \\
Parental Influence (PI) & 3.55 & .66 \\
Teachers' Morality (PM) & 3.60 & .86 \\
Pedagogy in Teaching (PT) & 3.27 & .56 \\
\hline
\end{tabular}

Table 2: Pearson Correlation Coefficients between Students' Motivation and Three Factors (Parents, Teaching Pedagogy and Teachers' Morality)

\begin{tabular}{|c|c|c|c|}
\hline Students' Motivation & Parents (PI) & Morality (TM) & Pedagogy (TP) \\
\hline \multicolumn{2}{|c|}{ Pearson Correlation.594** } & $.378^{* *}$ & $.220 * *$ \\
\hline Sig. (2-tailed) & .000 & .002 & .000 \\
\hline $\mathrm{N}$ & 170 & 170 & 170 \\
\hline
\end{tabular}

**Correlation is significant at the 0.01 level (2-tailed)

Tables 3-6 present further details for all items under students' motivation in learning Islamic education and the factors that might influence this motivation i.e. Parents Involvement (PI), and Teachers' Morality (TM) and Teaching Pedagogy (TP) using descriptive statistics, arranged from the items with highest mean scores at the top to the lowest mean scores at the bottom of the Tables. 
Table 3: Descriptive Statistics for Students' Motivation in Learning Islamic Education

\begin{tabular}{|c|c|c|c|c|c|c|}
\hline No & Items & $\begin{array}{l}\text { SA \&A } \\
n(\%)\end{array}$ & $\begin{array}{l}\text { NU } \\
n(\%)\end{array}$ & $\begin{array}{l}\text { SD \&D } \\
n(\%)\end{array}$ & M & SD \\
\hline 1 & $\begin{array}{l}\text { Studying Islamic Education subject is important } \\
\text { because it will enable me to better understand and } \\
\text { appreciate the Islam way of life. }\end{array}$ & $\begin{array}{l}129 \\
(75.9)\end{array}$ & $\begin{array}{l}31 \\
(18.2)\end{array}$ & $\begin{array}{ll}10 \\
(5.8)\end{array}$ & 4.12 & .10 \\
\hline 2 & $\begin{array}{l}\text { I would like to know more about Islamic Education } \\
\text { subject. }\end{array}$ & $\begin{array}{l}114 \\
(67.1)\end{array}$ & $\begin{array}{l}49 \\
(28.8)\end{array}$ & $\begin{array}{l}7 \\
(4.2)\end{array}$ & 3.92 & .96 \\
\hline 3 & $\begin{array}{l}\text { I want to learn Islamic Education subject so well } \\
\text { that it will become natural to me. }\end{array}$ & $\begin{array}{l}117 \\
(68.8)\end{array}$ & $\begin{array}{l}40 \\
(23.5)\end{array}$ & $\begin{array}{l}13 \\
(7.6)\end{array}$ & 3.88 & .99 \\
\hline 4 & $\begin{array}{l}\text { I would like to learn as much Islamic Education } \\
\text { subject as possible. }\end{array}$ & $\begin{array}{l}118 \\
(69.4)\end{array}$ & $\begin{array}{l}39 \\
(22.9)\end{array}$ & $\begin{array}{l}13 \\
(7.7)\end{array}$ & 3.82 & .93 \\
\hline 5 & $\begin{array}{l}\text { Studying Islamic Education subject is important } \\
\text { because it will allow me to meet and converse with } \\
\text { more and varied people. }\end{array}$ & $\begin{array}{l}111 \\
(65.3)\end{array}$ & $\begin{array}{l}43 \\
(25.3)\end{array}$ & $\begin{array}{l}16 \\
(9.4)\end{array}$ & 3.80 & .97 \\
\hline 6 & $\begin{array}{l}\text { The more I learn Islamic Education subject the more } \\
\text { I like it. }\end{array}$ & $\begin{array}{l}102 \\
(60)\end{array}$ & $\begin{array}{l}56 \\
(32.9)\end{array}$ & $\begin{array}{l}12 \\
(7)\end{array}$ & 3.79 & 1.04 \\
\hline 7 & $\begin{array}{l}\text { I have a strong desire to know all aspects of Islamic } \\
\text { Education subject. }\end{array}$ & $\begin{array}{l}111 \\
(65.3)\end{array}$ & $\begin{array}{l}48 \\
(28.2)\end{array}$ & $\begin{array}{l}11 \\
(6.5)\end{array}$ & 3.77 & .91 \\
\hline 8 & $\begin{array}{l}\text { Compared to my other subjects, I like Islamic } \\
\text { Education subject least of all (Recoded) }\end{array}$ & $\begin{array}{l}94 \\
(55.3)\end{array}$ & $\begin{array}{l}39 \\
(22.9)\end{array}$ & $\begin{array}{l}37 \\
(21.7)\end{array}$ & 3.54 & 1.25 \\
\hline 9 & $\begin{array}{l}\text { I really work hard to learn Islamic Education } \\
\text { subject. }\end{array}$ & $\begin{array}{l}78 \\
(45.9)\end{array}$ & $\begin{array}{l}75 \\
(44.1)\end{array}$ & $\begin{array}{l}17 \\
(10)\end{array}$ & 3.47 & .91 \\
\hline 10 & $\begin{array}{l}\text { The spiritual development of the students is } \\
\text { possible mainly by learning Islamic Education } \\
\text { subject. }\end{array}$ & $\begin{array}{l}77 \\
(45.3)\end{array}$ & $\begin{array}{l}77 \\
(45.3)\end{array}$ & $\begin{array}{l}16 \\
(9.4)\end{array}$ & 3.47 & .97 \\
\hline 11 & $\begin{array}{l}\text { I haven't any great wish to learn more than the } \\
\text { basics of Islamic Education subject (Recoded) }\end{array}$ & $\begin{array}{l}81 \\
(47 .)\end{array}$ & $\begin{array}{l}50 \\
(29.4)\end{array}$ & $\begin{array}{l}39 \\
(23)\end{array}$ & 3.35 & 1.12 \\
\hline 12 & $\begin{array}{l}\text { I learn Islamic Education subject because it is my } \\
\text { school requirement (Recoded) }\end{array}$ & $\begin{array}{l}71 \\
(41.8)\end{array}$ & $\begin{array}{l}39 \\
(22.9)\end{array}$ & $\begin{array}{l}60 \\
(35.3)\end{array}$ & 3.11 & 1.37 \\
\hline 13 & $\begin{array}{l}\text { I keep up to date with Islamic Education subject by } \\
\text { working on it almost every day. }\end{array}$ & $\begin{array}{l}44 \\
(25.9)\end{array}$ & $\begin{array}{l}82 \\
(48.2)\end{array}$ & $\begin{array}{l}44 \\
(25.9)\end{array}$ & 3.00 & .91 \\
\hline \multirow[t]{2}{*}{14} & $\begin{array}{l}\text { If it were up to me, I would spend all of my time } \\
\text { learning Islamic Education subject. }\end{array}$ & $\begin{array}{l}47 \\
(27.6)\end{array}$ & $\begin{array}{l}68 \\
(40.0)\end{array}$ & $\begin{array}{l}55 \\
(32.4)\end{array}$ & 2.94 & 1.11 \\
\hline & Mean and Standard Deviation & & & & 3.58 & 0.47 \\
\hline
\end{tabular}

Note: SA\&A= Strongly Agree \& Agree, NU= Neutral, SD\&D= Strongly Disagree \& Disagree

Table 3 shows that the majority of participants agreed and strongly agreed that Islamic Education is very important for them, and they are very willing and enthusiastic to learn more about Islamic Education. It helps them to appreciate and improve their life. Besides, they have expressed their willing to spend time to learn other school subjects. 
Table 4: Descriptive Statistics for Parents' Influence

\begin{tabular}{|c|c|c|c|c|c|c|}
\hline No & Items & $\begin{array}{l}\text { SA \&A } \\
n(\%)\end{array}$ & $\begin{array}{l}\mathrm{NU} \\
n(\%)\end{array}$ & $\begin{array}{l}\text { SD \&D } \\
n(\%)\end{array}$ & $\mathbf{M}$ & SD \\
\hline 1 & $\begin{array}{l}\text { My parents feel that it is very important for me to } \\
\text { learn Islamic Education subject. }\end{array}$ & $\begin{array}{l}123 \\
(72.4)\end{array}$ & $\begin{array}{l}31 \\
(18.2)\end{array}$ & $\begin{array}{l}16 \\
(9.4)\end{array}$ & 4.00 & 1.10 \\
\hline 2 & $\begin{array}{l}\text { My parents feel that I should continue studying } \\
\text { Islamic Education subject all through my life. }\end{array}$ & $\begin{array}{l}112 \\
(65.9)\end{array}$ & $\begin{array}{l}37 \\
(21.8)\end{array}$ & $\begin{array}{l}21 \\
(12.3)\end{array}$ & 3.86 & 1.10 \\
\hline 3 & $\begin{array}{l}\text { My parents try to help me to learn Islamic } \\
\text { Education subject. }\end{array}$ & $\begin{array}{l}109 \\
(64.1)\end{array}$ & $\begin{array}{l}36 \\
(21.1)\end{array}$ & $\begin{array}{l}25 \\
(14.7)\end{array}$ & 3.80 & 1.18 \\
\hline 4 & $\begin{array}{l}\text { My parents urge me to seek help from my teacher } \\
\text { if I am having problem with Islamic Education } \\
\text { subject. }\end{array}$ & $\begin{array}{l}86 \\
(50.6)\end{array}$ & $\begin{array}{l}49 \\
(28.8)\end{array}$ & $\begin{array}{l}35 \\
(20.6)\end{array}$ & 3.48 & 1.15 \\
\hline 5 & $\begin{array}{l}\text { My parents are very interested in everything I do } \\
\text { during my Islamic Education subject. }\end{array}$ & $\begin{array}{l}60 \\
(35.3)\end{array}$ & $\begin{array}{l}76 \\
(44.7)\end{array}$ & $\begin{array}{l}34 \\
(20)\end{array}$ & 3.20 & 1.09 \\
\hline 6 & $\begin{array}{l}\text { My parents think I should devote more time to } \\
\text { studying Islamic Education. }\end{array}$ & $\begin{array}{l}58 \\
(34.1)\end{array}$ & $\begin{array}{l}72 \\
(42.4)\end{array}$ & $\begin{array}{l}40 \\
(23.5)\end{array}$ & 3.17 & 1.10 \\
\hline \multirow[t]{2}{*}{7} & $\begin{array}{l}\text { My parents force me to learn Islamic Education } \\
\text { subject. (Recoded) }\end{array}$ & $\begin{array}{l}45 \\
(26.5)\end{array}$ & $\begin{array}{l}45 \\
(26.5)\end{array}$ & $\begin{array}{l}80 \\
(47)\end{array}$ & 3.29 & 1.33 \\
\hline & Mean and Standard Deviation & & & & 3.55 & 0.66 \\
\hline
\end{tabular}

Note: SA\&A= Strongly Agree \& Agree, NU= Neutral, SD\&D= Strongly Disagree \& Disagree

Table 4 reveals that the majority of the participants agreed and strongly agreed that their parents always motivate and help them to learn Islamic Education subject. Their parents also spend further time to read up on Islamic Education, and ask them to seek help from their teachers to facilitate learning the content of Islamic Education.

Table 5: Descriptive Statistics for Teachers' Morality

\begin{tabular}{lllllll}
\hline No & Items & $\begin{array}{l}\text { SA\%A } \\
\text { No.\% }\end{array}$ & $\begin{array}{l}\text { NU } \\
\text { No.\% }\end{array}$ & $\begin{array}{l}\text { SD\%D } \\
\text { No.\% }\end{array}$ & M & SD \\
\hline $\mathbf{1}$ & My Islamic education subject teacher reminds me of & 105 & 44 & 21 & 3.72 & 1.06 \\
& my roles as a student and a Muslim. & $(61.8)$ & $(25.9)$ & $(12.3)$ & & \\
$\mathbf{2}$ & My Islamic education subject teacher is & 98 & 52 & 20 & 3.65 & 1.12 \\
& approachable. & $(57.7)$ & $(30.6)$ & $(11.8)$ & & \\
$\mathbf{3}$ & My Islamic education subject teacher is considered a & 99 & 49 & 22 & 3.63 & 1.10 \\
& good model & $(58.2)$ & $(28.8)$ & $(13)$ & & \\
$\mathbf{4}$ & My Islamic Education teacher takes an effort to & 85 & 64 & 21 & 3.52 & 1.02 \\
& instill Islamic values (religious and moral) in class. & $(50)$ & $(37.6)$ & $(12.3)$ & & \\
$\mathbf{5}$ & My Islamic Education teacher has a reasonable & 79 & 73 & 18 & 3.48 & .94 \\
& $\begin{array}{l}\text { repertoire of Islamic moral stories for moral } \\
\text { inculcation }\end{array}$ & $(46.5)$ & $(42.9)$ & $(10.5)$ & & \\
\hline & Mean and Standard Deviation & & & & $\mathbf{3 . 6 0}$ & $\mathbf{0 . 8 6}$ \\
\hline
\end{tabular}

Note: SA\&A= Strongly Agree \& Agree, NU= Neutral, SD\&D= Strongly Disagree \& Disagree

Table 6 shows the majority of participants agreed and strongly agreed that their teachers' morality plays an important role in their learning Islamic Education subject. The participants look at their teachers as their role models because teachers remind them with their roles as Muslims, have good characters, are approachable, instill or inculcate values into students and have a wide knowledge in Islamic Education. 
Table 6: Descriptive Statistics for Teaching Pedagogy in Islamic Education

\begin{tabular}{|c|c|c|c|c|c|c|}
\hline No & Items & $\begin{array}{l}\text { SA \&A } \\
n(\%)\end{array}$ & $\begin{array}{l}\text { NU } \\
n(\%)\end{array}$ & $\begin{array}{l}\text { SD \&D } \\
n(\%)\end{array}$ & $\mathbf{M}$ & SD \\
\hline 1 & My teacher delivers the lesson well. & $\begin{array}{l}100 \\
(58.8)\end{array}$ & $\begin{array}{l}36 \\
(21.2)\end{array}$ & $\begin{array}{l}34 \\
(20)\end{array}$ & 3.56 & 1.10 \\
\hline 2 & $\begin{array}{l}\text { My teacher uses story-telling method to teach } \\
\text { Islamic education subject. }\end{array}$ & $\begin{array}{l}95 \\
(55.8)\end{array}$ & $\begin{array}{l}36 \\
(21.2\end{array}$ & $\begin{array}{l}39 \\
(23)\end{array}$ & 3.44 & 1.17 \\
\hline 3 & $\begin{array}{l}\text { My teacher allows us to ask different questions } \\
\text { during the lesson }\end{array}$ & $\begin{array}{l}79 \\
(46.5)\end{array}$ & $\begin{array}{l}51 \\
(30.0)\end{array}$ & $\begin{array}{l}40 \\
(23.5)\end{array}$ & 3.35 & 1.25 \\
\hline 4 & $\begin{array}{l}\text { My teacher uses lecture method to teach Islamic } \\
\text { education subject. ( Recoded) }\end{array}$ & $\begin{array}{l}75 \\
(44.2)\end{array}$ & $\begin{array}{l}42 \\
(24.7)\end{array}$ & $\begin{array}{l}53 \\
(31.2)\end{array}$ & 3.28 & 1.24 \\
\hline 5 & $\begin{array}{l}\text { My teacher prefers to teach rather than ask } \\
\text { question during Islamic Education class. } \\
\text { (Recoded) }\end{array}$ & $\begin{array}{l}69 \\
(40.9)\end{array}$ & $\begin{array}{l}60 \\
(35.3)\end{array}$ & $\begin{array}{l}41 \\
(24.1)\end{array}$ & 3.23 & 1.13 \\
\hline \multirow[t]{2}{*}{6} & $\begin{array}{l}\text { My teacher uses discussion method while } \\
\text { teaching Islamic Education subject. }\end{array}$ & $\begin{array}{l}61 \\
(35.9)\end{array}$ & $\begin{array}{l}36 \\
(21.2)\end{array}$ & $\begin{array}{l}73 \\
(42.9)\end{array}$ & 2.79 & 1.37 \\
\hline & Mean and Standard Deviation & & & & 3.27 & 0.56 \\
\hline
\end{tabular}

Note: SA\&A= Strongly Agree \& Agree, NU= Neutral, SD\&D= Strongly Disagree \& Disagree

Table 5 shows that most of the participants strongly agreed and agreed that their teachers deliver that Islamic classes well and encourage them to ask and answer questions in the class. Teachers also use the story-telling approach. However, participants agreed that their teachers do not use discussion methods compared to other methods. This implies that teachers need to use more student-centered learning strategies to make students more involved in the discussion.

\section{DISCUSSION}

Data analyses revealed that the participants have quite high motivation level in learning Islamic Education. This implies that students will learn the subject better and apply what they learn in their daily life affairs. Admittedly, they have found that Islamic Education subject is important for them because it enables them to better understand and appreciate the Islamic way of life. Oseni (2012) found out that students appear to have a general positive feeling toward Islamic studies, as it is very relevant to them. Saliva (2016) further explained that when students are motivated they persist longer at learning tasks, spend more time studying, read more deeply, remember more of what they read, and get better grades in their classes.

However, the level of students' motivation in learning Islamic Education could be influenced by various factors caused by the students or other parties. For instance, Silvia (2016) found that students' personal factors affect their motivation and influence their attitude towards learning Islamic education subject. Zaiton (2012) stated that the influence of parents is seen as an important factor in moulding the students' character and their Islamic worldview. In Islam, the parents' role and responsibility for their children's education and shaping their personalities are mooted in the Qur'an and Sunnah. For instance, in Qur'an Allah (s.w.t) mentions the story of Luqman who has asked his son to possess the good attributes and characteristics; "0 my son! Establish regular prayer, enjoin what is just, and forbid what is wrong: and bear with patience constancy whatever betide thee; for this is firmness [of purpose] in [the conduct of] affairs. And swell not thy cheek [for pride] at men, nor walk in insolence through the earth; for Allah loved not any arrogant boaster. And be moderate in thy pace, and lower thy voice; for the harshest of sounds without doubt is the braying of the ass" (Qur'an 31:17-19). The Prophet Mohammed (s.a.w) also highlights this role in a popular Hadith, "Surely! Every one of you is a guardian and is responsible for his charges: The Imam (ruler) of the people is a guardian and is responsible for his subjects; a man is the guardian of his family (household) and is responsible for his subjects; a woman is the guardian of her husband's home and of his children and is responsible for them; and the slave of a man is a guardian of his master's property and is 
responsible for it. Surely, every one of you is a guardian and responsible for his charges." (Sahih al-Bukhari, 7138, Book 93, Hadith 2). In fact, the significant influence of parents' involvement in their children's academic achievement and their motivation and attitude toward education has been thoroughly studied in other contexts or settings (Chen, 2005; Jeynes, 2003; Epstein 1995; Epstein \& Sheldon, 2006; Kabarere, Muchee, Makewa \& Role, 2013; Phillipson \& Phillipson, 2007; Sheldon \& Epstein, 2005).

In addition, teachers' morality is also seen as one of the factors that might affect students' motivation in learning Islamic Education. Zaiton (2012) pointed out that many concerned individuals, including students always consider teachers' personalities or characters in the teaching and learning process. Hamid (2007) found that teachers are seen as the models for students; not only in academic learning but also in personality and moral judgment. Students also owe them the same respect, trust and obedience given to their parents' at home. He concluded that teachers should practice what they preach and show kindness and compassion to students, and educate them with an open, smiling face. Quick (2004) found out that teachers of Islamic Education are aware of basic Islamic moral value that can be imparted to their students by regarding its vitality in all domains life. Consistent with that, the teachers believe that a position of these moral is of great value in the upbringing of a complete man and a good vicegerent on earth.

Furthermore, teaching approaches and methods used in Islamic Education classes might affect students' motivation in learning the subject. Adedoyin (2011) stressed that teachers need to combine or integrate pedagogical knowledge and content knowledge to meet students' needs and diversity as well as to involve them in the class in best manner. In Quick (2004), the respondents showed that teaching approaches and methods motivate them in learning. Therefore, teachers should be aware of the teaching methods used in the classroom.

\section{CONCLUSION}

This study revealed that a majority of the participants were positively motivated in earning Islamic Education subject. The parents take active role in motivating them learning Islamic Education and Teachers' morality plays almost the same role. Though Islamic Education are using interactive teaching methods, which motivate students to learn Islamic Education, they should use more effective teaching methods to further motivate students to learn Islamic Education and be able to apply it in their life. The study has provided useful and necessary information for the school administrations, teachers of Islamic Education, parents and students. This study included only one Islamic schools and used descriptive and correlation analyses, hence, more quantitative research is demanded to be conducted on larger samples and using other statistical techniques. Qualitative research is also needed to get more in-depth information on students' motivation in learning Islamic Education.

\section{References}

Abbas, P. G., Lei-Mei, L., \& Narjes, B. S. (2012). A study on the role of motivation in foreign language learning and teaching. International Journal of Modern Education and Computer Science 7, 9-16.

Abdul Rahman, S. A. (1982). Educational Theory: A Qur'anic outlook. Makkah Al- Mukarramah: Umm Al-Qura University.

Adnan Abd Rashid. (2014). Islamic paradigms for women's education and their roles to bring up Tawhidic Ummah. Asia Journal of Management Sciences \& Education, 3(2).

Adedoyin, 0. 0. (2011). The impact of teachers' in-depth pedagogical mathematical content knowledge in academic performance: European Journal of Education Studies, 3(2).

Alavi, S. M. Ziauddin. (1988). Muslim educational thought in middle Ages. New Delhi: Atlantic Publishers and Distributors. 
Al-attas, S. M. N. (1979). Preliminary thoughts on the nature of knowledge and the definition and aims in educations. London: Hodder \& Stoughton, 19-47.

Alizi, A., \& Mohammad Zaki, S. (2005). Psychology of motivation from an Islamic perspective. Paper presented at $3^{\text {rd }}$ International Seminar on Learning and Motivation. Organized by Faculty of Cognitive Sciences \& Education, Universiti Utara Malaysia, Kedah, Malaysia.

Azeez, A. O., \& Adeshina, S. T. (2013). Islamic studies in Nigeria: problems and prospects. International Journal of Humanities and Social Science, 3(2).

Badrasawi, Kamal J I and Preece, Abdul Shakour Duncan and Hashim, Che Noraini and Nik Abdullah, Nik Md. Saiful Azizi(2017) The concept of murabbi in Muslim education with reference to selected teaching methods of the prophet Muhammad (s.a.w). Al-Shajarah, Special Issue: Education. pp. 331-362. ISSN 1394-6870.

Chen, J. J.-L. (2005). Relation of Academic Support From Parents, Teachers, and Peers to Hong Kong Adolescents' Academic Achievement: The Mediating Role of Academic Engagement. Genetic, Social, and General Psychology Monographs, 131(2), 77-127.

Epstein, J. L. (1995). School/family/community partnerships. Phi Delta Kappan Bloomington, 76(9), 701.

Epstein, J. L., \& Sheldon, S. B. (2006). Moving forward: Ideas for research on school, family, and community partnerships. SAGE Handbook for Research in Education: Engaging Ideas and Enriching Inquiry, (April), 117-138.

Hamid, R. A. (2007). Al-Ghazali on moral education. Journal of Moral Education, 36(3), 309-319.

Jeynes, W. H. (2003). A Meta-Analysis: The Effects of Parental Involvement on Minority Children's Academic Achievement. Education and Urban Society, 35(2), 202-218. http://doi.org/10.1177/0013124502239392

Kabarere, V., Muchee, T., Makewa, L. N., \& Role, E. (2013). Parental Involvement in High and Low Performing Schools in Gasabo District, Rwanda. International Journal about Parents in Education, 7(1), 30-42.

Marwan, I. K. (2000). Morals and manners in Islam. Kuala Lumpur: Islam Book Trust.

Mohd, A. C. N. \& Ahmad, Y. K. (2012). Teacing of Islamic doctrine and beliefs in school subject content knowledge and pedagogical considerations. International Journal of Humanities and Social Science, 2(11).

Mohd shahril, A. R., \& Sidek, B. (2013). Educator's ADAB infusing Islamic manner and Islamic work ethics in teaching profession. WEL International Academic Proceedings. Antalaya, Turkey.

Mohamad Johdi Salleh \& Abdul Karnaen. Hierarchy Of 7m-Teacher-Leader From Islamic Perspectives. Al-Shajarah, Special Issue: Education. pp. 157-195. ISSN 1394-6870

Pallant, J. (2013). SPSS Survival Manual (4th Ed.). Allen \& Unwin: Australia.

Phillipson, S., \& Phillipson, S. N. (2007). Academic Expectations, Belief of Ability, and Involvement by Parents as Predictors of Child Achievement: A Cross-Cultural Comparison. Educational Psychology, 27(3), 329-348.

Oseni, R. A (2012). Factors influencing students' motivation and attitude towards Islamic studies in Lagos state Nigeria. (IIUM) Unpublished PhD thesis.

Quick, A. H. (2004). Advice to an Islamic school teacher. Cape town: International Board of Educational Research and Resources (IBERR).

Rafiei, B. (2002). Ideas of muslim scholars of education and its foundations (3) Tehran, samt.

Samsoo, S., Mohd, A. H., Nordin, S. H., Sharifah, K. P. B. \&Sofiyah, l. k. (2001). Islamic Behavior among Muslim teachers in the public primary school in the Soutren Thailand. Paper presented in the $3^{\text {rd }}$ international conference on humanities and social science. Facuulty of liberal art, prince of Songkla University.

Sheldon, S. B., \& Epstein, J. L. (2005). Involvement Counts : Family and Community Partnerships and Mathematics Achievement. The Journal of Educational Research, 98(4), 196-206

Silvia, P. J. (2006). Exploring the psychology of interest. New York: Oxford University Press.

Smith, K (2005). Teacher educators' expertise: what do novice teachers and teacher say? Teacher and teacher 21, 177-192.

Yadullah kazmi. (1996). The notion of murabbi in Islam critique of trends in comtemporary education. Islamabad: Islam Research Institute, International Islamic Universirty Islamabad Pakistan.

Yusuf A. A. The Meanings Of The Holy Qur'an. Accessed on Friday, 13 September 2018. http://www.islam101.com/quran/yusufAli/ 
Muhammed-Lawal, A. A., Abd Rashid, A., \& Badrasawi, K. J. I. (2018). Are Secondary School Students Motivated to Learn Islamic Education? Advances in Social Sciences Research Journal, 5(11) 442-452.

Zaiton, M. \& Hishamuddin, S. (2012). Factors affecting students' interest in learning Islamic education. Journal of Education and Practice, 3(13), 81-86. 